\title{
PEMBERDAYAAN, IBU RUMAHTANGGA KELOMPOK INDUSTRI TAHU BERBASIS PRODUK ANEKA OLAHAN TAHU UNTUK MENINGKATKAN PENDAPTAN KELUARGA DI MASA PANDEMI COVID-19 DI DESA LAMBUSA KABUPATEN KONAWE SELATAN
}

Nur Asizah1, Rosnawintang ${ }^{2}$, Muh. Nur Afiat ${ }^{3}$, Jamal Nasir Baso ${ }^{4}$

Fakultas Ekonomi dan Bisnis Universitas Halu Oleo

Email: nurasizah975@gmail.com

\section{RINGKASAN}

Kegiatan abdimas ini terintegrasi dengan PKMI-UHO yang dilaksanakan disesuaikan dengan kondisi saat ini (masa pandemic covid 19), dimana masyarakat Pada masa pandemic covid 19 ini telah membawa dampak negative terhadap sendi-sendi ekonomi masyarakat, pendapatan masyarakat menjadi menurun dengan keterbatasan aktivitas ekonomi. Banyak masyarakat yang kehilangan pekerjaan (menganggur)dan juga para produsen mengalami kerugian seperti yang dialami oleh industri tahu tempe dan masyarakat sekitar yang menyebabkan penurunan pendapatan. Salah satu solusi dengan mengembangkan home industry yaitu pembuatan aneka olahan tahu baik produk camilan atau dengan frozen food dan dipasarkan secara online. Kegiatan ini diharapkan dapat meningkatkan pendapatan masyarakat dengan hanya bekerja dirumah. Pelaksanaan abdimas ini berfocus pada dua hal pertama terkait dengan pelatihan dalam menghasilkan proddan siap saji juga frozen food, dan kedua adalah memberikan pelatihan meliputi praktek pembuatan secara individu dan kelompok praktek pengemasan, pemasaran online produk frozen food melalui marketing channel secara online. Pelaksanaan kegiatan ini diikuti oleh 1717 orang ibu Adapun frozen food yang dihasilkan dalam adalah bakso tahu, pempek tahu, tahu walik dan batagor serta stik tahu. Peserta pelatihan sangat antusias mengikuti kegiatan ini dikarena memberikan keterampilan yang bermanfaat meningkatkan pendapatan.

\section{Kata kunci: Peningkatan Pendapatan Masyarakat; Dampak Covid-19; Aneka Olehan Tahu}

\section{A. Analisis Situasi}

Dampak dari virus corona dialami Produsen Tempe Tahu (Gakoptindo) kondisi ini juga dialami oleh industri tahu di Tangerang selatan, Industri pembuatan tahu mengalami penurunan produksi dari 40 ton perbulan menjadi 17 ton sedangkan harga kedele juga sedang tinggi dari 9000 per kilogram menjadi 6500 perkilogram. Selanjudnya keresahan yang sama di alami Perajin tahu di Kabupaten Lebak, Provinsi 
Banten, sejak tiga pekan terakhir terancam gulung tikar akibat penyebaran virus corona atau COVID-19. Perajin tahu cukup terpukul, karena penjualan menurun hingga mencapai 80 persen dari hari biasanya, sehingga terpaksa memberhentikan empat pegawainya yang Biasanya, omzet mencapai Rp5 juta,, namun kini hanya Rp1 juta per hari. Selain Sejumlah perajin Tahu rumahan di Kota Kendari, Sulawesi Tenggara, alami kenaikan kedelai terus melambung, mengancam usaha mereka. Salahsatu pemilik Ny Parto, 40 tahun, pembuat tahu yang terletak di sekitar Puuwatu, Kendari kenaikan harga kedelai, memaksanya untuk menaikan harga jualan percetakan Tahunya. Satu cetakan tahu ia jual kisaran 25 Ribu Rupiah dari harga biasanya 20 Ribu Rupiah.

Tidak jauh berbeda yang yang dialami di Desa lambusa Biaya input produksi dan biaya tenaga kerja Konawe Selatan secara signifikan mempengaruhi penerimaan industri kecil tahu. Padahal Industri kecil tahu dikecamatan ini mampu menjadi komoditas yang berkontribusi relatif besar dan menjadi komoditas basis ekonomi di Kecamatan Konda.

Alternatif strategi pengembangan industri kecil tahu di Kabupaten Konsel adalah memperluas jangkauan daerah pemasaran industri kecil tahu, meningkatkan citra produk guna membidik kelas konsumen yang lebih tinggi melalui desain kemasan dan merek, membangun jejaring kerjasama bisnis, regional branding, melakukan penetrasi terhadap rantai suplai dan pengendalian harga kedelai, mengembangkan kapasitas kewirausahaan pengelola, mengoptimalkan kinerja produksi, menjaga komitmen dukungan dari pemerintah dan pihak lain, mengembangkan teknologi industri tahu yang tepat guna, mempermudah akses kepada lembaga keuangan, menjaga mutu dan kualitas produk, memanfaatkan bahan baku tahu alternatif, inovasi guna diversifikasi produk tahu, optimalisasi nilai ekonomi limbah industri tahu.

Program pengabdian bagi masyarakat ini akan dimplementasikan pada Ibu Rumahtangga Kelompok Industri Tahu untuk mengikuti Bimbingan di maksud. Program pengabdian ini merupakan kegiatan pemberdayaaan untuk meningkatkan 
kompetensi Sumber Daya Manusia, hal ini dapat dicapai melalui berbagai kegiatan pelatihan nonformal, Salah satunya kegiatan tim UHO adalah berupa kegitan pelatihan Ibu Rumahtangga Kelompok Industri Berbasis Produk Aneka Olahan Tahu Untuk Meningkatkan Pendaptan Keluarga Di Masa Pandemi Covid-19 Di Desa Lambusa Kabupaten Konawe Selatan.

Adapun Permasalahan yang dihadapi produsen tahu dan tempe di wilayah tersebut berada pada kreatifitas inovasi, manajemen kelompok dan mananajemen pemasaran tidak diperhatikan. Program pengabdian ini upaya memberikan bimbingan pengabdian masyarakat berbasisi pada produk Aneka olahan tahu sebagai kreatifitas dan inovasi yang pada akhirnya hasil yang didapatkan dapat membantu masyarakat dalam memecahkan masalah yakni bagaimana upaya untuk membantu para Ibu Rumahtangga Kelompok Industri tersebut untuk menambah nilai produksi tahu menjadi berbagai jenis olahan tahu guna meningkatkan pendapatan keluarga

Tujuan yang ingin dicapai dalam bimbingan ini lanjutnya, untuk membentuk atau mengembangkan sekelompok masyarakat yang mandiri secara ekonomi dan mampu meningkatkan produktifitas para produsen dan pengecer tahu dan tempe di Desa Lambusa Kecamatan Konda Kabupaten Konawe Selatan.

\section{B. Metode Pelaksanaan}

Metode pelaksanaan yang digunakan oleh Tim UHO dalam kegiatan ini yaitu bimbingan dan pelatihan pembuatan Aneka olahan tahu dengan mengundang dan memberi penyuluhan dan bimbingan berupa bimbingan dan pelatihan. diharapkan melalui bimbingan dan pelatihan ini anggota masyarakat dan terutama Ibu-ibu Dasawisma dapat mengembangkan jiwa wirausaha sekaligus dapat memproduksi dan memasarkan hasil produksinya nanti.

Diharapkan pula melalui pelatihan ini warga mampu dalam pemenuhan akan kebutuhan gizi dengan memproduksi berbagai macam olahan berbahan tahu. Hal ini tentunya akan dapat meningkatnya pendapatan mengingat bahan tersedia di wilayah mitra cukup banyak dengan harga yang murah. 
Kegiatan Pelaksanaan meliputi pemberian pelatihan, praktek pembuatan produk secara individu dan praktek pengemasan produk yang merupakan hasil dari serangkaian pelatihan

a. Tahap Pelaksanaan

Pelaksaan kegiatan ini akan dilaksanakan dengan urutan kegiatan sebagai berikut: sosialisasi kegiatan kepada masyarakat yang dipilih, rembuk dengan masyarakat tempat pelaksanaan, identifikasi hasil diskusi dengan masyarakat, membuat draf untuk kegiatan masyarakat berdasarkan hasil rembuk, pelatihan pembuatan dan pemasaran produk Adapun yang sasaran pelatiahan pembuatan dan pemasaran produk terdiri dari masyarakat dan pelaku Industru tahu dan tempe Masyarakat yang pilih adalah mereka yang mempunyai keinginan untuk berusaha membuat membuat aneka olahan tahu dalam rangka meningkatkan pendapatan. Jumlah masyarakat yang dilibatkan sebanyak 17 orang.

Indikator yang digunakan untuk menentukan keberhasilan pelaksanaan kegiatan sebagai berikut ; 1) Terlaksananya pelatihan produk Aneka Olahan Tahu 2). Peserta Pelatihan mampu membuat sendiri produksi tahu dan memasarkan dengan cara on line dan of line.

\section{Hasil dan Pembahasan}

Pelaknaan kegiatan ini melibatkan 2 orang mahasiswa dan para ibu dilaksanakan dengan dua tahap. Tahap pertama adalah penyampaian materi. terdiri dari tiga sesi, sesi pertama; tentang wirausaha home industry produk makanan siap saji dan (Frozend Food), sesi kedua; Praktik pembuatan makanan siap saji dan Frozend Food (melalui video) semacam tutorial yang telah dibuat sebelumnya oleh dosen pembimbing, sesi ketiga; Pemasaran Online Produk Makanan Siap Saji (Frozen Food). Penyampaian materi dilaksanakan selama satu hari yang diikuti oleh seluruh peserta baik mahasiswa maupun masyarakat. 
Tahap kedua pelaksanaan pelatihan. Pelatihan produk siap saji frozen food berjalan dengan lancar dan sesuai dengan rencana yang telah ditetapkan sebelumnya. Pelatihan tersebut dilakukan selama 1 (satu) hari penuh yakni dimulai pagi sampai sore hari. Adapun produk dan produk frozen foodyang dihasilkan dalam pelatihan ini adalah bakso tahu, pempek tahu, tahu walik dan batagor serta stik tahu.

Bakso tahu, pempek tahu, tahu walik dan batagor serta stik tahu. merupakan beberapa jenis makanan yang banyak diminati oleh masyarakat dan seperti yang kita ketahui bahwa jenis makanan ini ternyata dapat dibuat dengan memodifikasikan bahan tahu dengan bahan lain sepertti daging yang telah digiling dan ikan yang telah digiling. Daging sapi atau ayam giling juga daging ikan giling kemudian dicampur dengan berbagai bahan yaitu seperti tepung dan bumbubumbu beserta bahan lain yang juga telah dihaluskan, daging giling yang telah dicampur kemudian di bentuk bulat-bulatan lalu di rebus/kukus hingga matang.

\section{Bakso tahu}

Bahan-bahan yang digunakan dalam proses pembuatan bakso Tahu sapi yaitu sebagai berikut:

\section{Bahan:}

- 500 gr daging sapi giling - 30 tahu goreng, goreng belah 2 segitiga

- 4 batang daun bawang, iris halus

- $150 \quad$ gr $\quad$ terigu

- $250 \mathrm{gr}$ tepung kanji/tapioka

- 1 bungkus saset kaldu bubuk jamur

- 2 sdt garam

- $150 \mathrm{ml}$ air untuk kukusan

\section{Bumbu halus:}

- 5 siung bawang putih - 1 sdt merica butir

- 1 sdt bawang goreng

Adapun cara pembuatan bakso tahu daging sapi yaitu sebagai berikut: 
- Masukkan dalam food frosesor daging, bawang putih, daun bawang, bumbu halus, garam dan kaldu bubuk lalu tuang air es sedikit-sedikit hingga menjadi bubur tepung.

Air es dipakai sesuai kebutuhan aja bisa kurang atau lebih.

- Masukkan campur tepung kanji/tapioka sedikit-sedikit campur rata sampai kalis

Isi tahu dengan adonan, bakso lalu kukus sampai matang tiiriskan dan sajikan.

\section{Pempek Tahu}

Bahan-bahan yang digunakan dalam proses pembuatan Pempek Tahu yaitu sebagai berikut:

\section{Bahan:}

- 500 gram daging Ikan Tenggiri

- 350 gram sagu tani

- 12 buah tahu-belah dua menjadi segitiga

- 1 butir telur

- $125 \mathrm{ml}$ air

\section{Bumbu halus:}

- 2 siung bawang putih-haludkan

- $1 \mathrm{sdm}$ garam

sdt kaldu jamur

- 1 sdt merica

- $250 \mathrm{ml}$ air

Adapun cara pembuatan bakso tahu daging sapi yaitu sebagai berikut:

- Haluskan daging ikan dan telur menggunakan chopper. Pindahkan ke wadah lalu tambahkan garam,merica, kaldu jamur dan air aduk rata. Kemudian masukkan sagu dan aduk hingga benar benar tercampur rata.

- Goreng tahu sebentar, lalu belah bagian tengahya kemudian isi dengan adonan ikan.

Panaskan minyak goreng pempek dengan api kecil hingga matang.

- Angkat dan tiriskan.

Sajikan pempek dengan kuah cuko.

\section{Tahu Walik}


Bahan-bahan yang digunakan dalam proses pembuatan Tahu Walik yaitu sebagai berikut:

Bahan:

- $\quad 500$ gr ikan giling

- 20 tahu goreng, belah 2 segitiga

- 4 batang daun bawang, iris halus

- 150 gr terigu

- 250 gr tepung kanji/tapioka

- 1 bungkus saset kaldu bubuk

- 2 sdt garam

- $150 \mathrm{ml}$ air panas atau secukupnya

\section{Bumbu halus:}

- 5 siung bawang putih - 1 sdt merica butir

Adapun cara pembuatan bakso tahu daging sapi yaitu sebagai berikut:

- Masukkan dalam wadah terigu, daun bawang, bumbu halus, garam dan kaldu bubuk lalu tuang air panas sedikit-sedikit hingga menjadi bubur tepung. Air dipakai sesuai kebutuhan aja bisa kurang atau lebih.

- Masukkan ikan giling, campur rataMasukkan tepung kanji/tapioka sedikit-sedikit campur rata dengan menggunakan centong kayu Balik potongan tahu goreng.

Isi tahu dengan adonan, lalu goreng sampai matang Tiriskan dan sajikan.

\section{Batagor}

Bahan-bahan yang digunakan dalam proses pembuatan Tahu Walik yaitu sebagai berikut:

\section{Bahan:}

- 3 buah tahu putih

- 8 sdm tepung kanji

- 2 sdm tepung terigu

- 3 buah daun bawang

- 1 buah telur

- $500 \mathrm{ml}$ air

\section{Bumbu halus:}

- 2 siung bawang putih (haluskan)

- Secukupnya garam, lada dan royco

- Bumbu kacang :

- 100 gr kacang tanah (goreng)

- 2 siung bawang putih (goreng)

- 6 cabai (goreng)

- sesuai selera Gula merah sisih 
- 2 lembar daun jeruk

- secukupnya Kecap

Adapun cara pembuatan bakso tahu daging sapi yaitu sebagai berikut:

- Lumatkan tahu dalam wadah

- Tambahkan tepung kanji,tepung terigu,daun bawang,telur serta bawang putih,lada,garam dan royco aduk hingga tercampur rata

- Panaskan minyak,lalu goreng adonan menjadi kecil-kecil se ukuran sendok (bentuk sesuai selera), goreng hingga bewarna kecoklatan

- Cara membuat bumbu kacang : masukkan kacang, bawang putih,cabai pakai blender lebih cepat (saya ulek pakai tangan) lalu masak diwajan panas bersama daun jeruk tambahkan air,guram dan penyedap sesuai selera

\section{Sajikan bersama batagornya}

Pada akhir pelatihan dilakukan praktik seluruh peserta Seluruh peserta sangat antusias mengikuti praktik produk dan frozen food hal ini menunjukkan bahwa pelatihan yang dilakukan dapat meningkatkan keterampilan peserta dalam produk frozen food. Sementara pada sesi pemasaran off line dan online produk dan produk frozen food maka produk-produk tersebut yang telah dibuat dan sudah dikemas dengan menarik.

\section{Kesimpulan}

Setelah Pelaksanaan kegiatan ini, dapat disimpulkan beberapa hal, yakni;

- Pelatihan pembuatan produk berjalan dengan sangat baik, peserta sangat antusias mengikuti pelatihan tersebut, dikarenakan memberikan keterampilan yang bermanfaat meningkatkan pendapatan.

- Adapun produk dan produk frozen food yang dihasilkan dalam pelatihan ini adalah bakso tahu, pempek tahu, tahu walik dan batagor serta stik tahu 
Sementara pemasaran online frozen food dapat dilakukan dengan menggunakan berbagai media sosial, seperti; WA, Facebook dan Instagram.

\section{E. UCAPAN TERIMAKASIH}

Kegiatan ini dapat terlaksana berkat dukung dari berbagai pihak, olehnya itu kami tim pelaksana menyampaikan rasa terima kasih kepada seluruh pihak khususnya kepada Lembaga Penelitian dan Pengabdian Kepada Masyarakat (LPPM) Universitas Halu Oleo yang telah membiayai secara penuh kegiatan ini.

\section{DAFTAR PUSTAKA}

Brilio.net -https://brilicious.brilio.net/masak-yuk/20-resep-olahan-tahu-kekinian-murahdan-lezat-190822j.html

https://ekonomi.bisnis.com/read/20200403/257/1222325/industri-tempe-tahu-sudahpenjualan-turun-terpukul-kurs-pula

https://metro.tempo.co/read/1407117/harga-bahan-pangan-di-jakarta-utara-pekankedua-november-2020-cenderung-stabil

https://rmco.id/lihat-foto/megapolitan/33176/produksi-tahu-mengalami-penurunan-dipandemi-corona

https://imcnews.id/pengusaha-tahu-terancam-gulung-tikar-di-tengah-pandemi-covid-19 http://albertusagungp.blogspot.co.id/2016/09/essay-tentang-pengabdianmasyarakat.html 